\title{
Examining the Relationship between Teachers' Individual Innovativeness and Professionalism
}

\author{
Hanifi Parlar ${ }^{1} \&$ Ramazan Cansoy ${ }^{2}$ \\ ${ }^{1}$ Faculty of Humanities and Social Sciences, Istanbul Commerce University, Sütlüce Campus, Beyoğlu, Istanbul, \\ Turkey \\ ${ }^{2}$ Faculty of Letters, Department of Educational Sciences, Karabük University, Karabük, Turkey \\ Correspondence: Hanifi Parlar, Istanbul Commerce University, Sütlüce Mah. İmrahor Cad. No: 90, Sütlüce, \\ Beyoğlu, İstanbul, Turkey. Tel: 90-532-677-9965. E-mail: hanifiparlar@gmail.com
}

Received: March 7, 2017 Accepted: April 20, $2017 \quad$ Online Published: July 29, 2017

doi:10.5539/ies.v10n8p1 URL: https://doi.org/10.5539/ies.v10n8p1

\begin{abstract}
The aim of this study was to examine the relationship between teachers' individual innovativeness and their teacher professionalism. The participants were 567 teachers working in elementary, middle and high schools located across Istanbul. The data were gathered through the "Individual Innovativeness Scale" and the "Teacher Professionalism Scale". In data analysis, arithmetic means and Pearson Product-Moment Correlation Analysis were used. The results of the study showed that the teachers' characteristics of individual innovativeness fell into the group of early majority. The teachers' innovativeness was found to be at the highest level in the dimension of openness to experience. There was a weak positive relationship between the individual innovativeness characteristics of openness to experience and opinion-leading, and teacher professionalism, which was significant.
\end{abstract}

Keywords: teachers, individual innovativeness, professionalism

\section{Introduction}

Teachers' professional behaviours reduce the differences among students with socioeconomic disadvantages (OECD [Organisation for Economic Co-operation and Development], 2016). These behaviours of teachers are also positively related to the quality of instructional practices (Cohen \& Hill, 2000), classroom management strategies (Guskey, 1986), improving student learning (Hoque, Alam, \& Abdullah, 2011; McDonald, Son, Hindman \& Morrison, 2005; Poekert, 2012), school development (Cansoy \& Parlar, 2016), teacher job satisfaction (Altınkurt \& Yilmaz, 2014), confidence in colleagues (Dean, 2011), teacher self-efficacy and confidence in the school principal (Koşar, 2015). Teacher professionalism refers to enhancing the standards towards student learning and the quality of practices in improving instruction (Hargreaves, 2000). Therefore, it is expected that positive outcomes will be yielded in the quality of instruction as teachers perform professional behaviours. In this regard, to be able to understand teacher professional behaviours and have a more in-depth analysis and interpretation, this concept needs to be examined in relation to organisational and personal characteristics.

Teacher professional behaviours have been the focus of many studies in recent years. These studies investigated the relationship of teacher professional behaviours with the bureaucratic structure of schools (Cerit, 2012; Karaca, 2015), burnout (Çelik, 2015), school culture (Kılınç, 2014; Tschannen-Moran, 2009), school development (Cansoy \& Parlar, 2016; Hoque, Alam \& Abdullah, 2011), confidence in the administrator and teacher self-efficacy (Koşar, 2015). One of the concepts that can be related to teacher professional behaviours is individual innovativeness. Innovativeness is one's level of being willing and opened to change (Hurt, Joseph \& Cook, 1977), and adopting an innovation to different degrees (Rogers, 1995). Schools are systems in which innovations spread and are turned into practice quickly. Accordingly, teachers play an important role in making innovative practices and curriculum changes functional (Fullan, 2007). In fulfilling this vital role, teachers are expected to perform professional behaviours by having characteristics such as being innovative and productive, and managing changes (Cumming \& Owen, 2001). Teacher professional behaviours include designing in- and out-of-class activities, improving instruction, and being able to solve problems in extraordinary ways (Carlgren, 1999). Depending on their innovative characteristics, teachers develop a capacity for problem-solving (Özmen \& 
Sönmez, 2007). It is important to have innovators that can make students think freely by going beyond the traditional curriculum, and facilitate and encourage acquiring new pieces of knowledge (Fullan \& Pomfret, 1977). It can thus be argued that characteristics of individual innovativeness have a positive influence on teachers' performing professional behaviours. Innovative teachers can exhibit professional behaviours to a higher extent by improving their knowledge, skills and experienced through new ideas and experiences. Therefore, there may be a relationship between individual innovativeness and professional behaviours. In this respect, the existing research can provide findings regarding what the characteristics of individual innovativeness are towards developing professional behaviours in teachers.

However, in the Turkish context, most of the studies on the characteristics of individual innovativeness are observed to focus on teacher candidates (Çuhadar, Bülbül, \& Ilgaz, 2013; Konokman, Yokuş, \& Yelken, 2016; Özgür, 2013; Şahin, 2016), whereas those that examine in-service teachers are quite limited (K1lıc, 2015; Kösterelioğlu \& Demir, 2014). Studies on teacher candidates reported the existence of a relationship between the levels of innovativeness, and critical thinking skills (Özgür, 2013), techno-pedagogical competencies (Çuhadar, Bülbül, \& Ilgaz, 2013), levels of accepting information technologies (Şahin, 2016) and innovative material design skills (Konokman, Yokuş, \& Yelken, 2016). On the other hand, those on in-service teachers revealed a relationship of individual innovativeness with teacher leadership (Kösterelioğlu \& Demir, 2014) and lifelong learning skills (Kılıç, 2015). Therefore, there is a need for further studies that examine the relationship between teachers' characteristics of individual innovativeness and different variables. Data obtained from such studies can provide significant insights to researchers and practitioners. Besides, no studies that directly address the relationship between individual innovativeness and professional behaviours have been encountered in the literature. In this respect, the present study is expected to contribute to the relevant literature.

\section{Teacher Professionalism}

Professional behaviours refer to general efforts for enhancing the quality of education (Carlgren, 1999; Phelps, 2003). Professionalism is regarded as improving the quality of instructional behaviours and setting higher standards in education (Hargreaves, 2000). Teacher professionalism is related to teachers' commitment in their work, collaboration with colleagues, respecting and helping each other, job involvement and behaviours towards enhancing the quality of instruction (Tschannen-Moran, Parish, \& DiPaola, 2006). In addition, professionalism is about one's commitment to perfectionism, setting a model for others, taking responsibility for the quality of education (Agezo, 2009), and working with a researcher's logic to develop him/herself in the area (Kincheloe, 2004). Teacher professionalism features enhancing the quality of education in general, and improving the learning of students as the core of any school in particular (Darling-Hammond, 1990; Hargreaves, 2000).

Different approaches are adopted with respect to the characteristics of teacher professionalism. In a report published by OECD (2016), teacher professionalism is discussed with reference to autonomy, collaboration with colleagues and professional knowledge. Autonomy refers to active participation in decision-making processes, and strengthening the teaching profession. This dimension highlights teachers' right to comment on the curriculum, selection of materials, course objectives, disciplinary practices at school and student assessment. The dimension of collaboration with colleagues is about the contributions made to the development of colleagues, guiding those who start the teaching profession and teachers' improving each other's instruction through observations. Professional knowledge, on the other hand, relates to going through training before practising teaching, continuous professional development and participation in fieldworks. In another approach, Darling-Hammond (1990) emphasises the characteristics of teacher professionalism that include teachers' making decisions in the profession, responding to student needs, having certain competencies, forming professional standards, and acting based on an ethical principle. In this way, student learning can be improved to higher levels. According to Evans (2011), teacher professionalism consists of dimensions that are behavioural, attitudinal and intellectual. Behavioural dimension is about influencing the elements of teacher competences and student learning. Attitudinal dimension refers to teacher perceptions and views of the profession. As for intellectual dimension, it features the active employment of instructional methods, and original ideas.

Teacher professionalism is also discussed within the historical process in terms of its development. According to Hargreaves (2000), teacher professionalism went through four different periods. These periods were pre-professionalism, professional autonomy, collaboration with colleagues, and post-professionalism. In pre-professionalism, teaching was seen as a busy profession administratively, but a simple profession technically. In professional autonomy, teachers were effective in curriculum studies and decision-making, and had a better status. In the period of collaboration with colleagues, they established professional learning communities, and were involved in discussions about effectiveness. In post-professionalism, the school and the teaching profession were questioned and redefined, and social groups became influential on the school. 


\section{Individual Innovativeness}

The perception of an idea, practice or object as new according to an individual, group or community is described as an innovation (Rogers, 1995). Moreover, innovation is also referred to as the efforts to improve an existing situation (MNE [Ministry of National Education], 2010), and different approaches to yield desired results (Smith, 2009). Innovativeness indicates openness and willingness to change (Hurt, Joseph, \& Cook, 1977), developing, adopting and implementing an innovation (Yuan \& Woodman, 2010), and the degree to which an innovation is adopted by others (Rogers, 1995).

Innovativeness is related to the differences among individuals based on their reactions to innovations. Accordingly, innovativeness is classified as a behavioural characteristic, a general personality characteristic, and a specific area characteristic. The behavioural approach highlights the time factor in adopting an innovation. The general personality characteristic reveals the desire to experience innovations. On the other hand, the specific area characteristic is the level at which individuals adopt an innovation in a specific area they are interested. An innovative individual is open to experiences, go after original suggestions, transform information, and put ideas into practice (Leavitt \& Wallton, 1975).

As other professions, teaching plays an important role in the spread and approval of innovations (Rogers, 1995). Innovative teachers encourage students to recognise and discover their potential, whereas setting high standards for student learning (MNE, 2010). Teachers can play innovative roles in their classes depending on their characteristics. While doing this, they can consider the relationships between classroom climate, communication, delivering lessons through different methods and student learning (Jaskyte, Taylor, \& Smariga, 2009).

The categories and dimensions of innovativeness were adopted from Rogers' classification (1995) in the present study. In this classification, individuals are divided into the categories of innovators, early-adopters, early-majority, late-majority and laggards/traditionalists depending on their reactions to innovativeness. Innovators can take risks, like to experience new things, are social, and can use different thinking skills. Early-adopters guide people about innovations, follow developments and set a model in practice. Early-majority prefers to stay away from risk, and focuses on the benefits brought by innovations. Late-majority is cautious against innovations, and initially expects others to experience these innovations. Traditionalists are attached to their traditions; prefer the innovations that have been successful, and adopt them based on results. On the other hand, the dimensions of innovativeness are resistance to change resistance to change, opinion-leading, openness to experience and risk-taking. Resistance to change refers to negative feelings against innovations and change; opinion-leading to the originality of ideas individuals develop within a group and the characteristics that enable them to stand in the front; openness to experience to being in search of innovations and the willingness to different experiences; and risk-taking to overcoming uncertain situations and individuals' showing their determination.

Certain organisational and personal variables lead to the development of teacher professionalism. Teachers' confidence in their school administrators and having a high level of self-efficacy beliefs (Koşar, 2015), school culture at school, task-oriented culture and bureaucratic culture (K1linç, 2014), and bureaucratic structure of the school (Cerit, 2012) positively affect professional behaviours. Besides, having effective communication and collaboration with colleagues is of great importance in performing professional behaviours (Tschannen-Moran, 2009).

Various innovative behaviours support teachers' professional behaviours. These are the personal characteristics such as creativity, passion and sacrifice, the skills that refer to the characteristics of experiential learning and managing the change, the knowledge on innovativeness, pedagogy and professional development, and the values regarding continuous development (Cumming \& Owen, 2001). On the other hand, new ideas can be developed depending on employees' taking more responsibility and authority (Al Zahrani, Zamil, Oraiqat, \& Alsalhi, 2012). When teachers take more initiatives and responsibilities, they can initiate the change in environments that encourage collaboration and openness (Inbar, 1996). Innovative teachers act in a unique way when improving the curriculum and teaching students. They constantly develop themselves, teach classes effectively, and design and implement new practices towards student learning (Ritchhart, 2004). While doing these, teachers attach importance to collaboration with colleagues because their levels of innovativeness improve and problems are solved in more unique ways within such activities (Uzkurt, 2010). Moreover, teachers who collaborate with colleagues become more innovative, while innovative teachers are more willing to collaboration (Cumming \& Owen, 2001). Consequently, teachers who exhibit more characteristics of innovativeness are expected to perform more professional behaviours.

Based on the review and arguments presented above, it can be argued that there is a positive relationship 
between teachers' characteristics of individual innovativeness and their professional behaviours. In this respect, the present study examined the relationship between these two variables. The following research questions guided the study:

1) What are teachers' levels of individual innovativeness and professionalism?

2) Is there a significant relationship between teachers' levels of individual innovativeness and professionalism? If yes, at what level?

\section{Method}

\subsection{Model}

This study was designed in the correlational model to examine the relationship between teachers' individual innovativeness and professionalism. The dependent variable of the study was teacher professionalism, while the independent variables were the dimensions of individual innovativeness including resistance to change, opinion-leading, openness to experience and risk-taking.

\subsection{Participants}

The participants were 567 teachers from elementary, middle and high schools located across Istanbul in the 2016-2017 school year. Among these participants, 321 were female (57\%), and 246 were male (43\%). There were 270 elementary school teachers $(48 \%), 118$ middle school teachers $(21 \%)$ and 179 high school teachrs (32\%). Their age average was 37.03 years, while their average duration of service in their schools was 4.02 years. In overall, their duration of service in the profession was 13.26 years.

\subsection{Data Gathering Tools}

The information gathered with regard to the participants' demographic characteristics included gender, age, year of service and level of school. The Individual Innovativeness Scale and the Teacher Professionalism Scale were employed to gather the research data.

"Individual Innovativeness Scale"; This scale was developed by Hurt, Joseph and Cook (1977) and adapted to Turkish by Kılıçer and Odabaşı (2010). The scale reveals individuals' perceptions regarding their levels of adopting innovations. A 5-point grading scale is used in the instrument that has options ranging from "(1) Strongly Disagree" to "(5) Strongly Agree”. The variance explained in the scale that includes 20 items and four dimensions is $52.21 \%$.The Cronbach's Alpha coefficients calculated for reliability are .82 for the whole scale, .82 for resistance to change, .73 for opinion-leading, .77 for openness to experience and .62 for risk-taking. The characteristics of individual innovativeness are categorised as innovators, early-adopters, early-majority, late-majority and laggards/traditionalists. In the scale, scores above 80 are described as Innovators, scores between 69 and 80 as Early Adopters, scores between 57 and 68 as Early Majority, scores between 46 and 56 as Late Majority, scores below 46 as Laggards/Traditionalists. As for the levels, those who get 68 points and above are described as highly innovative, and those who get 64 points and below are considered low in innovativeness. Innovators are open to different experiences, early adopters guide others about innovations, early majority is cautious against innovations, late majority approach to innovations doubtfully, and traditionalists prefer to observe the results before accepting the chance immediately. The dimensions of innovativeness are resistance to change, opinion-leading, openness to experience and risk-taking. Resistance to change refers to negative feelings against innovations and change; opinion-leading to the originality of ideas individuals develop within a group and the characteristics that enable them to stand in the front; openness to experience to being in search of innovations and the willingness to different experiences; and risk-taking to overcoming uncertain situations and individuals' showing their determination. Sample items include "I like trying out new ideas", and "I think I am an active individual in my social circle" (K1liçer \& Odabaşı, 2010).

Whether the 20 items and four factors in the individual innovativeness scale fitted the data in this study was examined. Confirmatory factor analysis (CFA) was performed for this purpose. The results of CFA showed that the model had a good fit with the data. The factor loading values of the items in the scale ranged between .43 and $.83,\left(\mathrm{X}^{2}=355.20 ; \mathrm{p}<.05 ; \mathrm{df}=162 ; \chi 2 / d f=2.19 ; \mathrm{RMSEA}=.046 ; \mathrm{CFI}=.94 ; \mathrm{GFI}=.94\right)$. The Cronbach's Alpha coefficient calculated for the reliability of the scale was .76 in the present study. The coefficients of the dimensions were .85 for resistance to change, .73 for opinion-leading, .74 for openness to experience, and .74 for risk-taking.

"Teacher professionalism"; This scale was developed by Tschannen-Moran, Parish, and DiPaola (2006), and adapted to Turkish by Cerit (2012). It contained eight items and was rated on a 5-point Likert scale with options ranging from "Strongly Disagree" to "Strongly Agree". The scale includes items that reveal teachers' levels of 
performing professional behaviours. These items are related to teachers' professional collaboration towards ensuring student learning, professional development, job involvement, high expectations of success and communication with other members of the school community (Tschannen-Moran, Parish \& DiPaola, 2006). The variance explained in the scale is $61.62 \%$. The Cronbach's Alpha coefficient calculated for the whole scale is .90 (Cerit, 2012). Sample items are as follows: "Teachers provide strong social support to their colleagues" and "Teachers are dedicated to help their students". This scale was employed in different studies.

Whether the 8 items in the teacher professionalism scale fitted the data in this study was examined. Confirmatory factor analysis (CFA) was performed for this purpose. The results of CFA showed that the model had a good fit with the data. The factor loading values of the items in the scale ranged between .31 and $.78,\left(X^{2}=57.49 ; p<.05\right.$; $\mathrm{df}=17 ; \chi 2 / d f=3.38 ; \mathrm{RMSEA}=.065 ; \mathrm{CFI}=.97 ; \mathrm{GFI}=.97)$. The Cronbach's Alpha coefficient calculated for the reliability of the scale was .91 in the present study.

\subsection{Data Analysis}

The data were analysed using SPSS. Missing values were firstly assigned an average value. The normality of the data was then checked. The skewness and kurtosis values of the data ranged between -.59 and .50. Skewness and kurtosis values between +1 and -1 show that data are close to or distant from normal distribution (Şencan, 2005). Based on the Q-Q plot along with the skewness and kurtosis values, it was assumed that the distribution of the data was normal. In order to answer the research questions in the study, the arithmetic means of the scores in the dimensions of teacher professionalism scale and those of individual innovativeness scale were calculated. The analyses were conducted based on these mean values. Pearson Product-Moment Correlation coefficient (r) was used to determine the relationships between the variables. The significance level was set at .05 . As for the fit indices used while conducting confirmatory factor analysis, GFI is accepted as good fit if the coefficient obtained from AGFI is .85 (Anderson \& Gerbing, 1984 \& Cole, 1987) or .90 (Kline, 2005; Schumacker \& Lomax, 1996) and above. Values obtained from RMSEA that are .10 and below are regarded as sufficient for fitness. The ratio of $\chi^{2} / \mathrm{df}$ being between $2-5$ refers to good fit, whereas it being lower than 2 refers to perfect fit (Jöreskog \& Sörbom, 2001).

\section{Findings}

In this section, the mean scores, standard deviations, results of the correlation analysis are presented with regard to innovativeness and professionalism.

Table 1. Arithmetical means in the dimensions of individual innovativeness, and teacher professionalism

\begin{tabular}{lccccc}
\hline Variables & $\mathrm{n}$ & $\mathrm{k}$ & $\mathrm{X}$ & $\mathrm{X} / \mathrm{k}$ & $\mathrm{SD}$ \\
\hline 1. Resistance to change & 567 & 8 & 19.52 & 2.44 & .72 \\
2. Opinion-leading & 567 & 5 & 19.05 & 3.81 & .56 \\
3. Openness to experience & 567 & 5 & 20.98 & 4.19 & .53 \\
$\begin{array}{l}\text { 4. Risk-taking } \\
\text { Individual innovativeness } \\
\text { characteristics [whole scale] }\end{array}$ & 567 & 2 & 7.04 & 3.52 & .86 \\
Professionalism & 567 & 20 & 66.59 & 3.49 & .41 \\
\hline
\end{tabular}

As is seen in Table 1 , the teachers' characteristics of individual innovativeness were found to fall into the group of early majority, $(\bar{X}=69.59)$. With regard to the sub-dimensions, the teachers perceived themselves as the most competent in openness to experience, which was followed by opinion-leading and risk-taking, respectively. Their resistance to change was observed to be below the moderate level. On the other hand, the teachers' professional behaviours were above the moderate level, $(\bar{X}=3.87)$.

Table 2. Teachers' levels of individual innovativeness

\begin{tabular}{lcc}
\hline Levels & Frequency & Percentage (\%) \\
\hline Highly innovative & 304 & 53.6 \\
Moderately innovative & 140 & 24.7 \\
Low in innovativeness & 123 & 21.7 \\
\hline
\end{tabular}

As can be seen in Table 2, 53.6\% of the teachers were highly innovative, $24.7 \%$ were moderately innovative, and 
$21.7 \%$ were low in innovativeness.

Table 3. Teachers' levels based on the categories of innovativeness

\begin{tabular}{lcc}
\hline Categories & Frequency & Percentage (\%) \\
\hline Innovator & 68 & 12.0 \\
Early adopter & 229 & 40.4 \\
Early majority & 238 & 42.0 \\
Late majority & 30 & 5.3 \\
Traditionalist & 2 & .4 \\
\hline
\end{tabular}

Based on the categories of innovativeness, $12 \%$ of the teachers were innovators, $40.4 \%$ were early adopters, $42 \%$ were early majority, $5.3 \%$ were late majority, and $0.4 \%$ were traditionalists.

\subsection{Relationship Between Variables}

Table 4. Relationship between the dimensions of individual innovativeness, and teacher professionalism

\begin{tabular}{|c|c|c|c|c|c|c|}
\hline Variables & Professionalism & $\begin{array}{c}\text { Resistance to } \\
\text { change }\end{array}$ & Opinion-leading & $\begin{array}{l}\text { Openness to } \\
\text { experience }\end{array}$ & Risk-taking & $\begin{array}{c}\text { Individual } \\
\text { innovativeness } \\
\text { [Whole Scale] }\end{array}$ \\
\hline Professionalism & 1 & -.04 & $.21^{* *}$ & $.24^{* *}$ & .01 & $.14^{* *}$ \\
\hline Resistance to change & & 1 & -.04 & $-.18^{* *}$ & .00 & $.32^{* *}$ \\
\hline Opinion-leading & & & 1 & $.62^{* *}$ & $.32^{* *}$ & $.69^{* *}$ \\
\hline $\begin{array}{ll}\text { Openness } & \text { to } \\
\text { experience } & \end{array}$ & & & & 1 & $.39^{* *}$ & $.65^{* *}$ \\
\hline Risk-taking & & & & & 1 & $.75^{* *}$ \\
\hline Individual & & & & & & \\
\hline innovativeness & & & & & & 1 \\
\hline [Whole Scale] & & & & & & \\
\hline$* * \mathrm{p}<.05$ & & & & & & \\
\hline
\end{tabular}

The correlation analysis revealed a weak positive correlation between professionalism and individual innovativeness $(r=.14 ; p<.05)$. As for the dimensions of individual innovativeness, teacher professionalism was positively and significantly related to opinion-leading $(r=.21 ; p<.05)$, and openness to experience $(r=.24 ; p<.05)$. However, the relationships of professionalism with resistance to change $(r=-.04 ; p>.05)$ and risk-taking $(r=.013$; $p>.05)$ were not significant.

\section{Discussion, Conclusion and Suggestions}

This study examined the relationship between teachers' characteristics of individual innovativeness, and their professional behaviours. The results revealed a weak relationship between individual innovativeness and professional behaviours. On the other hand, the teachers were found to fall into the innovativeness category of early majority, and were highly innovative. Moreover, their levels of professionalism were above the moderate level.

In terms of the characteristics of individual innovativeness, most of the teachers were found to be in the group of early majority. Similar findings are also reported in the literature (K1lıç, 2015). Individuals in the early majority approach to innovations with caution, do not like to take risks and focus on the benefits brought by innovations (Rogers, 1995). In this respect, it can be stated that the teachers would adapt to new in-class instructional practices towards increasing the quality of education late. The exam-focused structure of the education system may encourage teachers to maintain existing practices rather than adopt innovations. Following and employing new methods and techniques towards student learning at school are among the key leadership characteristics of teachers (Can, 2009). Innovativeness can spread across school if innovative educational approaches are examined and implemented (Xu \& Chen, 2010). If systematic changes are expected from schools, teacher should accept innovations and implement them in their classes (Gess-Newsome, Southerland, Johnston \& Woodbury, 2003). There is a need for innovators who can enable student to think critically, and guide them in structuring knowledge (Fullan \& Pomfret, 1977). Innovative teachers try to achieve student learning through extraordinary 
methods (Jaskyte, Taylor \& Smariga, 2009), help students recognise themselves and improve the quality of learning (MNE, 2010). As can be inferred, teachers' level of innovativeness should be improved from early majority to early adopters and innovators.

In the study, the teachers' characteristics of individual innovativeness mostly gathered around the dimensions of openness to experience and opinion-leading. Openness to experience refers to being in search of innovations, and the willingness to different experiences. On the other hand, opinion-leading means that teachers come to the fore in their communities with original ideas, and become effective with their opinions (K1lıç, 2015; Kösterelioğlu \& Demir, 2014). These dimensions being perceived at high levels can be seen as a positive result. Teachers' being open to experience and exhibiting behaviours of opinion-leading can be due to their collaborative works. This is because teachers may share certain experiences in group meetings or in teachers' lounge in schools. Teachers' openness to experience may enable them to have more collaboration with their colleagues. Innovation in education should be towards collaboration and gaining new experiences (Inbar, 1996). Individuals who adopt an innovation early are more often together with those who make the change possible (Rogers, 1995).

In the study, the teachers' perceptions of professionalism were found to be above the moderate level. The finding is similar to others reported in the literature (Çelik, 2015; K1lınç, 2014; Koşar, 2015). However, some studies reported lower levels of teacher professional behaviours (Bayhan, 2011; Cerit, 2012). Accordingly, it can be stated that the teachers' behaviours regarding student learning were positive, while the quality of their instructional practices were above the moderate level. The teachers' level of professionalism being above the moderate level can be due to their active participation in decision-making processes in recent years, and the authority given to them in material selection. Besides, teaching has become a profession that not everyone can practice easily because individuals can become teachers after a long period of training and a process of recruitment. It can then be argued that the teaching profession has started to gain an important status. There could also be other reasons behind the high perception of professionalism. According to an OECD report (2016), it is stated that teachers have certain powers regarding material selection and planning in the classroom. In the same report, it is indicated that with strong collaboration among colleagues and supporting professional development, teachers' job satisfaction and self-efficacy beliefs move up to higher levels, and the status of the profession gets better in the society. Consequently, although teacher professionalism was found to be above the moderate level in this study, it should be improved to higher levels. This is because positive changes can be observed in the quality of instruction and student learning depending on teachers' professional behaviours (Cohen \& Hill, 2000; Guskey, 1986). Teachers who perform professional behaviours collaborate with their colleagues (Rizvi \& Elliot, 2005), do not confine themselves with the existing status, and thus, have high expectations regarding the quality of education (Agezo, 2009). In this respect, teachers' professional behaviours may play a vital role in the solution of different problems at schools, and ensure raising well-educated individuals (Darling-Hammond, 1990). Although the teachers in the present study had a sufficient level of perception regarding their professionalism, different practices should be implemented to improve this level.

In the study, significant relationships, although not strong, were revealed between teachers' openness to experience and opinion-leading, which are the dimensions of individual innovativeness, and their professionalism. Teachers' being open to experience and opinion-leading are among important characteristics of innovativeness. Besides, professionalism emphasises quality practices towards improving instruction. Teachers' developing themselves in their profession and implementing practices to improve student learning are related to their innovativeness (Ritchhart, 2004), and innovative characteristics develop with collaboration among colleagues (Uzkurt, 2001). Originality, new ideas, adopting change and keeping one's self up-to-date are of great importance in teachers' professional behaviours. As professional collaboration increases, innovative characteristics develop (Cumming \& Owen, 2001). Therefore, it can be argued that teachers' professional behaviours can develop if they are open to experiences and lead with their opinions. Being attached to innovative processes is of significance for professional development (Inbar, 1996). Openness to experience and development is important for professional behaviours (Harrington, 1987). All professions require individuals to be open to innovations (Snoek, Swennen, \& Van der Klink, 2011). In this regard, the levels of performing professional behaviours are expected to increase with the characteristics of individual innovativeness.

According to the results of the study, the teachers' characteristics of individual innovativeness fell into the group of early majority. There can be an emphasis on practices to improve teachers' individual innovativeness from early majority to early adopters and innovators. If teachers do not develop their skills towards enhancing the quality of instruction, it will be more difficult for them to equip their students with the necessary knowledge and skills (Hargreaves, 1999). In this context, teachers can be encouraged to take part in innovative activities in and outside school to develop innovativeness. Individual, organisational and social obstacles can be in play regarding 
the development of this skill. Infrastructure of the organisation, access to information technologies, curricula and leadership are thus of great importance (K1lıçer, 2011). Therefore, a school culture towards enhancing innovativeness can be created. In the present study, the individual innovativeness dimensions of openness to experience and opinion-leading were found to be related to professionalism. From this perspective, a school culture should be formed which would support openness to experience and produce original ideas. Creating learning communities that would develop teachers' experiences and views can contribute to their professional behaviours. As for raising the quality of teachers, organising schools as professional learning communities can yield useful results (Bullough, 2007; Mangrum, 2004). Events can thus be planned to ensure that teachers come together more often in and outside school. On the other hand, the results of this study can be better explained through qualitative methods such as observations and interviews. With respect to further research, studies be conducted to develop scales that can measure the characteristics of innovativeness in the context of education, and provide us insights about evaluating teachers' innovativeness more effectively.

\section{References}

Agezo, C. K. (2009). School reforms in Ghana: A challenge to teacher quality and professionalism. IFE PsychologIA: An International Journal, 17(2), 40-64. https://doi.org/10.4314/ifep.v17i2.45302

Al Zahrani, A. A., Zamil, A. M., Oraiqat, A. Y. M., \& Alsalhi, N. (2012). The impact of antecedents supporting organizational innovation on employees' psychological empowerment: An empirical study of Saudi and jordanian industrial corporations. African Journal of Business Management, 6(24), 7329-7343. https://doi.org/10.5897/AJBM11.3032

Altınkurt, Y., \& Yılmaz, K. (2014). Öğretmenlerin mesleki profesyonelliği ile iş doyumları arasındaki ilişki. Sakarya University Journal of Education, 4(2), 57-71. https://doi.org/10.19126/suje.46033

Anderson, J. C., \& Gerbing, D. (1984). The effect of sampling error on convergence, improper solutions, and goodness-of-fit indices for maximum likelihood confirmatory factor analysis. Psychometrika, 49, 155-173. https://doi.org/10.1007/BF02294170

Bayhan, G. (2011). Öğretmenlerin profesyonelliğinin incelenmesi (Unpublished Doctoral Dissertation). Marmara Üniversitesi, İstanbul.

Bullough, R. V. (2007). Professional learning communities and the eight-year study. Educational Horizons, 85(3), 168-180. Retrieved from https://allthingsplc.secure.agroup.com/files/uploads/Bulloughplc.pdf

Can, N. (2009). Öğretmen liderliği. Ankara: Pegem Akademi.

Cansoy, R., \& Parlar, H. (2016, May). Öğretmen profesyonelizminin okul gelişimi ile olan ilişkisinin incelenmesi. In the Proceedings of $11^{\text {th }}$ National Congress on Educational Management (pp. 73-77). Kuşadası, Muğla.

Carlgren, I. (1999). Professionalism and teachers as designers. Journal of Curriculum Studies, 31(1), 43-56. https://doi.org/10.1080/002202799183287

Çelik, M. (2015). Öğretmenlerin mesleki profesyonelliği ile tükenmişlikleri arasındaki ilişki (Unpublished Master's Thesis). Dumlupınar Üniversitesi, Kütahya.

Cerit, Y. (2012). Okulun bürokratik yapısı ile sınıf öğretmenlerinin profesyonel davranışları arasındaki ilişki. Kuram ve Uygulamada Ë̆itim Yönetimi, 18(4), 497-521. Retrieved from http://dergipark.ulakbim.gov.tr/kuey/article/view/5000050487/5000047745

Cohen, D. K., \& Hill, H. C. (2000). Instructional policy and classroom performance: The mathematics reform in California. Teachers College Record, 102(2), 294-343. https://doi.org/10.1111/0161-4681.00057

Cole, D. A. (1987). Utility of confirmatory factor analysis in test validation research. Journal of Consulting and Clinical Psychology, 55, 1019-1031. https://doi.org/10.1037/0022-006x.55.4.584

Çuhadar, C., Bülbül, T., \& Ilgaz, G. (2013). Exploring of the relationship between individual innovativeness and techno-pedagogical education competencies of pre-service teachers. Elementary Education Online, 12(3), 797-807.

Cumming, J., \& Owen, C. (2001). Reforming Schools through Innovative Teaching. Australian College of Educatiors, Enterprise and Career Education Foundation and Dusseldorf Skills Forum, ACE Canberra.

Darling-Hammond, L. (1990). Teacher professionalism: Why and how? In A. Lieberman (Ed.), Schools as collaborative cultures: Creating the future now (pp. 25-50). New York, NY: The Falmer. 
Dean, S. D. (2011). Collegial leadership, teacher professionalism, faculty trust: predicting teacher academic optimism in elementary schools (Doctoral dissertation, The University of Alabama).

Evans, L. (2011). The 'shape' of teacher professionalism in England: Professional standards, performance management, professional development and the changes proposed in the 2010 white paper. British Educational Research Journal, 37(5), 851-870. https://doi.org/10.1080/01411926.2011.607231

Fullan, M. (2007). The new meaning of educational change. London: Routledge Falmer.

Fullan, M., \& Pomfret, A. (1977). Research on curriculum and instruction implementation. Review of Educational Research, 47(1), 335-397. https://doi.org/10.3102/00346543047002335

Gess-Newsome, J., Southerland, S. A., Johnston, A., \& Woodbury, S. (2003). Educational reform, personal practical theories and, dissatisfaction. American Educational Research Journal, 40(3), 731-767. https://doi.org/10.3102/00028312040003731

Guskey, R. (1986). Staff development and the process of teacher change. Educational Researcher, 15(3), 5-12 https://doi.org/10.3102/0013189X015005005.

Hargreaves, A. (2000). Four ages of professionalism and professional learning. Teachers and Teaching: Theory and Practice, 6(2), 151-182. https://doi.org/10.1080/713698714

Hargreaves, D. H. (1999). The knowledge-creating school. British Journal of Educational Studies, 47(2), 122-144. https://doi.org/10.1111/1467-8527.00107

Harrington, D. (1987). Beyond the Four Walls: Teacher Professionalism in Action. ERIC Number: ED291815

Hildebrandt, S. A., \& Eom, M. (2011). Teacher professionalization: Motivational factors and the influence of age. Teaching and Teacher Education, 27(2), 416-423. https://doi.org/10.1016/j.tate.2010.09.011

Hoque, K. E., Alam, G. M., \& Abdullah, A. G. K. (2011). Impact of teachers' professional development on school improvement an analysis at Bangladesh standpoint. Asia Pacific Education Review, 12(3), 337-348. https://doi.org/10.1007/s12564-010-9107-z

Hurt, H. T., Joseph, K., \& Cook, C. D. (1977). Scales for the measurement of innovativeness. Human Communication Research, 4, 58-65. https://doi.org/10.1111/j.1468-2958.1977.tb00597.x

Inbar, D. E. (1996). Planning For Innovation in Education. Retrieved from http://unesdoc.unesco.org/images/0011/001119/111952Eb.pdf

Jaskyte, K., Taylor, H., \& Smariga, R. (2009). Student and faculty perceptions of innovative teaching. Creativity Research Journal, 21(1), 111-116. https://doi.org/10.1080/10400410802633673

Jöreskog, K., \& Sörbom, D. (2001). LISREL 8.51. Mooresvile: Scientific Software.

Karaca, D. (2015). Illk ve ortaokullarda bürokratikleşme düzeyinin öğretmen profesyonelliğine etkisi (Unpublished doctoral dissertation). Pamukkale Üniversitesi, Denizli.

Kılıç, H. (2015). Illköğretim branş ögretmenlerinin bireysel yenilikçilik düzeyleri ve yaşam boyu öğrenme eğilimleri (Denizli ili örneği) (Unpiblished master's thesis). Pamukkale Üniversitesi, Denizli.

Kılıçer, K. (2011). Bilgisayar ve ögretim teknolojileri eğitimi ögretmen adaylarının bireysel yenilikçilik profilleri (Unpublished doctoral dissertation). Anadolu Üniversitesi, Eskişehir.

Kılıçer, K., \& Odabaşı, H. F. (2010) Bireysel yenilikçilik ölçeği (BYÖ): Türkçeye uyarlama, geçerlik ve güvenirlik çalışması, Hacettepe Üniversitesi Eğitim Fakültesi Dergisi, 38, 150-164.

Kılınç, A. Ç. (2014). Öğretmen profesyonelizminin bir yordayıcısı olarak okul kültürü. Eğitim ve Bilim, 39(174), 105-118.

Kincheloe, J. L. (2004). The knowledge of teacher education: Developing a critical complex epistemology. Teacher Education Quarterly, 31(1), 49-66.

Kline, R. B. (2005). Principle and practice of structural equation modeling. New York, NY: Guilford.

Konokman, G. Y., Yokus, G., \& Yelken, T. Y. (2016). Yenilikçi materyal tasarlamanın sınıf öğretmeni adaylarının yenilikçilik düzeylerine etkisi. Bartın Üniversitesi Ĕgitim Fakültesi Dergisi, 5(3), 857-878. https://doi.org/10.14686/buefad.v5i3.5000203433

Koşar, S. (2015). Öğretmen profesyonelizminin yordayıcıları olarak okul müdürüne güven ve öz yeterlik. Eğitim ve Bilim, 40(181), 255-270. 
Kösterelioğlu, M. A., \& Demir, F. (2014). Öğretmenlerin bireysel yenilikçilik düzeyinin öğretmen liderliğine etkisi. The Journal of Academic Social Science Studies, 26, 247-256. https://doi.org/10.9761/JASSS2271

Leavitt, C., \& Wallton, J. (1975). Development of a scale for innovativeness. Advances in Consumer Research, 2, 545-554.

Mangrum, J. (2004). The evolution of a professional learning community: The role of dialogue initiated through faculty Paideia seminars. University of North Carolina.

McDonald Connor, C., Son, S., Hindman, A. H., \& Morrison, F. J. (2005). Teacher qualifications, classroom practices, family characteristics, and preschool experience: Complex effects on first graders' vocabulary and early reading outcomes. Journal of School Psychology, 43(4), 343-375. https://doi.org/10.1016/j.jsp.2005.06.001

Milli Eğitim Bakanlı̆̆ı. (2010). Yenilikçi öğretmenler eğitimi:yenilikçi öğretmenler kaynak kitabı. Ankara: Milli Eğitim Bakanlığı. Retrieved from http://yenilikciogretmenler.meb.gov.tr/file.axd?file $=2010 \% 2 \mathrm{f} 3 \% 2 \mathrm{fY} \% \mathrm{C} 3 \%$ 96P_19.02.2010.pdf

OECD. (2016), Supporting Teacher Professionalism: Insights from TALIS 2013. OECD Publishing, Paris. https://doi.org/10.1787/9789264248601-en

Özgür, H. (2013). Bilişism teknolojileri öğretmen adaylarının eleştirel düşünme eğilimleri ile bireysel yenilikçilik özellikleri arasındaki ilişkinin çeşitli değişkenler açısından incelenmesi. Mersin Üniversitesi Ĕgitim Fakültesi Dergisi, 9(2), 409-420.

Özmen, F., \& Sönmez, Y. (2007). Değişim sürecinde eğitim örgütlerinde değişim ajanlarının rolleri. Fırat Üniversitesi Sosyal Bilimler Dergisi, 17(2), 177-198.

Phelps, P. H. (2003). Teacher professionalism. Kappa Delta Pi Record, 40(1), 7-11. https://doi.org/10.1080/00228958.2003.10516406

Poekert, P. E. (2012). Teacher leadership and professional development: Examining links between two concepts central to school improvement. Professional Development in Education, 38(2), 169-188. https://doi.org/10.1080/19415257.2012.657824

Ritchhart, R. (2004). Creative teaching in the shadow of the standards. Independent School, 63, 32-40.

Rogers, M. E. (1995). Diffusion of innovations (5th ed.). New York: Free Press.

Şahin, F. (2016). Öğretmen adaylarının bilişim teknolojileri kabul düzeyleri ile bireysel yenilikçilik düzeyleri arasındaki ilişkinin incelenmesi (Unpiblished master's thesis).Anadolu Üniversitesi, Eskişehir.

Schumacker, R. E., \& Lomax, R. G. (1996). A beginner's guide to structural equation modeling. Hilsdale, NJ: Erlbaum. https://doi.org/10.1080/10705519609540025

Şencan, H. (2005). Sosyal ve davranışsal ölçümlerde güvenilirlik ve geçerlilik. Ankara: Seçkin.

Smith, K. (2009). Innovation in public education: Problems and opportunities. Retrieved from http://www.newschools.org/files/innovation-in-education.pdf on 17.2.2017

Snoek, M., Swennen, A., \& van der Klink, M. (2011). The quality of teacher educators in the european policy debate: Actions and measures to improve the professionalism of teacher educators. Professional Development in Education, 37(5), 651-664. https://doi.org/10.1080/19415257.2011.616095

Tschannen-Moran, M. (2009). Fostering teacher professionalism in schools: The role of leadership orientation $\begin{array}{llll}\text { and trust. Educational Administration } & \text { Quarterly, 45(2), }\end{array}$ https://doi.org/10.1177/0013161X08330501

Tschannen-Moran, M., Parish, J., \& DiPaola, M. F. (2006). School climate and state standards: How interpersonal relationships influence student achievement. Journal of School Leadership, 16, 386-415.

Uzkurt, C. (2010). İnovasyon yönetimi: inovasyon nedir, nasıl yapılır ve nasıl pazarlanır. Ankara Sanayi Odası Yayın Organl, 39. Retrieved from http://www.aso.org.tr/b2b/asobilgi/sayilar/4dosyatemmuzagustos2010.pdf

Xu, Z., \& Chen, H. (2010). Research and Practice on Basic Composition and Cultivation Pattern of College Students' Innovative Ability. International Education Studies, 3(2), 51-55. https://doi.org/10.5539/ies.v3n2p51

Yuan, F., \& Woodman, R. W. (2010). Innovative behavior in the workplace: The role of performance and image outcome expectations. The Academy of Management Journal, 53(2), 323-342. 
https://doi.org/10.5465/AMJ.2010.49388995

\section{Copyrights}

Copyright for this article is retained by the author(s), with first publication rights granted to the journal.

This is an open-access article distributed under the terms and conditions of the Creative Commons Attribution license (http://creativecommons.org/licenses/by/4.0/). 